\title{
California stem-cell grants awarded
}

\section{First major round of research targeted at therapies takes off.}

The starting gun has fired for 14 research teams, based in California, who now have four years to make good on the therapeutic promise of stem cells.

On 28 October, the California Institute for Regenerative Medicine (CIRM) committed US $\$ 230$ million to teams of basic and clinical researchers aiming to move experimental stem-cell treatments into an investigational new-drug filing with the US Food and Drug Administration. Britain and Canada together paid an additional $\$ 43$ million for four of the grants, which will include work by researchers in those countries.

Robert Klein, chair of CIRM's board, calls the awarding of the grants a "historic day".

It is the most highly anticipated round of research grants yet awarded by the San Francisco-based agency, which was set up by a 2004 ballot measure to fund stem-cell research. At the time, federal funding for research on human embryonic stem-cell lines was restricted to the relatively small number of cell lines in existence in August 2001.

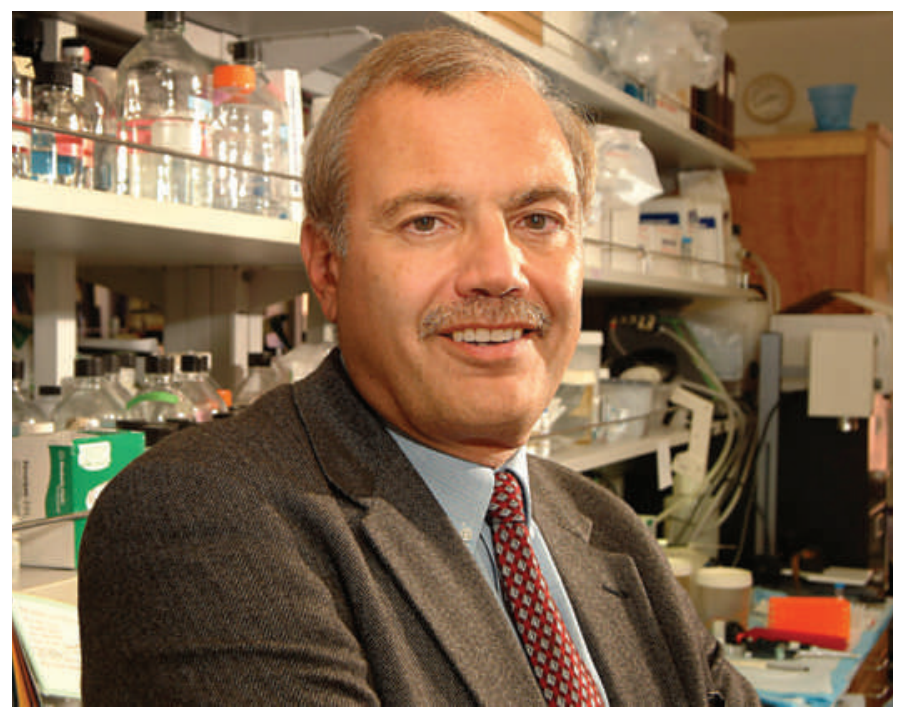

Dennis Slamon leads one of the teams to receive funding from CIRM.

of California, Los Angeles, who developed the breast cancer drug trastuzumab, sold by Genentech of South San Francisco - aim to target and destroy cancer stem cells, whose existence is still a matter of some debate.

Another grant will attempt to use induced pluripotent stem cells - which have many of the capabilities of embryonic stem cells but can be tailored to match individual patients - to treat a rare skin disease called epidermolysis bullosa.

Four other awards focus on modifying adult stem cells to treat HIV and brain tumours.

Observers say that the chances of one or more of the experimental therapies making it to the clinic are improved because many of them take similar approaches to techniques that have already been approved, and because many focus on adult stem cells.

Major scientific questions remain about using embryonic stem cells in humans. The first company intending to begin clinical trials involving human embryonic stem cells - Geron of Thousand Oaks in California - has faced repeated

Scientists outside the state say that the grants could help the stem-cell field as a whole. Sean Morrison, director of the University of Michigan Center for Stem Cell Biology in Ann Arbor, calls the awards "exciting".

"Developing an effective new treatment is a hard problem, and most good ideas won't lead to cures," he says. "But, without the resources from these disease-team grants, it would take much longer to distinguish between the good ideas that really work and the good ideas that don't quite work."

Other researchers have welcomed the awards, but note that many of the projects test ideas that are similar to work being funded elsewhere. The National Institutes of Health, for instance, is gearing up to fund research on new lines of human embryonic stem cells. It plans to spend nearly $\$ 1$ billion this year, not including money from the economic stimulus package, on research on adult and embryonic stem-cell lines in humans and other animals.

"The general [new-grant] portfolio strikes me as being similar to what is going on elsewhere," for many indications - to target cancer cells. Another grant will try to use a patient's own cardiac stem cells to repair damage from heart attacks, a controversial approach that is already being tested in patients. A fourth grant aims to modify patients' bone-marrow cells to correct the genetic defect that causes sickle-cell anaemia, then implant the cells back into patients.

A similar approach has been used to treat severe combined immunodeficiency disorder. "That would have been called gene therapy before, instead of stem-cell therapy, and there are a number of people doing that," Orkin points out.

\section{Broad disease range}

Four of the grants involve work on human embryonic stem cells, intending to treat diabetes, macular degeneration, amyotrophic lateral sclerosis and stroke. And three of the cancer grants - including one co-led by Dennis Slamon, an oncologist at the University setbacks in getting its trial going.

"For adult stem cells, moving from the lab to a clinical trial doesn't take nearly as long, and four years is not outrageous at all," says Robin Young, a Philadelphia-based publisher of an orthopaedics newsletter and organizer of an annual stem-cell meeting in New York. "I would say it's very likely that some of those are going to be in clinical trials by then."

Even therapies that aim to use adult stem cells are no sure thing. In September, Osiris Therapeutics of Columbia, Maryland, announced that its treatment made from cultured adult stem cells to treat graft versus host disease had failed.

However, a success by one of the grantees could be enough for CIRM to gain voters' approval to extend its 10-year lifespan beyond its initial approved expiry date of 2014 - or 2016, if counting from when CIRM funded its first grants. "Even if one of these ideas succeeds, it would be a huge success for CIRM that would justify all of their investment in this area," Morrison says.

Erika Check Hayden 